\title{
A RARE CLINICAL CASE OF AN ADVANCED PENILE CANCER IN A 52 YEAR-OLD MAN
}

\section{RZADKIE STADIUM PRZYPADKU ZAAWANSOWANEGO RAKA PRĄCIA U 52-LETNIEGO MĘŻCZYZNY}

\author{
Paweł Mika' ${ }^{1(A, B, C, D, E, F, G)}$, Maciej Kisiel $^{1(A, B)}$ \\ ${ }^{1}$ Regional Hospital in Biała Podlaska, Poland
}

Authors' contribution Wkład autorów: A. Study design/planning zaplanowanie badań B. Data collection/entry zebranie danych C. Data analysis/statistics dane - analiza i statystyki D. Data interpretation interpretacja danych E. Preparation of manuscript przygotowanie artykułu F. Literature analysis/search wyszukiwanie i analiza literatury G. Funds collection zebranie funduszy
Tables: 0

Figures: 6

References: 11

Submitted: 2017 Feb 21

Accepted: 2017 Apr 21

\section{Summary}

The following case study presents a rare advanced penile cancer in a 52 year-old man The diagnosis of penile cancer is not especially common. Patient with squamous cell carcinoma, which is the most prevalent type of penile cancer, undergo surgical treatment. The first part of the therapy covers a radical penectomy, and the second one - radical pelvic lymphadenectomy. Despite such a drastic surgical procedure, there was a need of further oncological treatment including an adjuvant chemotherapy. Unfortunately, the patient did not continue his treatment. Such advanced stages of penile cancer are very uncommon because of patients being aware of any changes in the genitourinary area. In the early stages of the disease, an isolated resection of penile change or a partial penectomy is usually a sufficient consideration. In such cases, overall survival rates are high. However, more advanced stages typically require a more radical treatment and a systemic approach including chemotherapy and radiotherapy. Then, the results of treatment and prognosis for the patients are not as good as in case of patients with early diagnosed problems.

Keywords: penile neoplasms, carcinoma, squamous cell, lymph node excision

\section{Streszczenie}

Poniższe studium przypadku przedstawia rzadkiego zaawansowanego raka prącia u 52-letniego mężczyzny. Rozpoznanie raka prącia nie jest szczególnie powszechne. Pacjent z rakiem płaskonabłonkowym, który jest najczęściej występującym rakiem prącia, przechodzi leczenie chirurgiczne. Pierwsza część terapii obejmuje radykalną penektomię, a druga radykalną limfadenektomię miednicy. Pomimo tak drastycznej procedury chirurgicznej, konieczne było dalsze leczenie onkologiczne, w tym chemioterapia adjuwantowa. Niestety, pacjent nie kontynuował leczenia. Takie zaawansowane stadium raka prącia jest bardzo rzadkie, ponieważ pacjenci są świadomi jakichkolwiek zmian w obszarze moczowopłciowym. We wczesnych stadiach choroby zwykle wystarczająca jest resekcja zmiany prącia lub częściowa penektomia. W takich przypadkach ogólne wskaźniki przeżycia są wysokie. Jednak bardziej zaawansowane stadia wymagają zazwyczaj bardziej radykalnego leczenia i podejścia systemowego, w tym chemioterapii i radioterapii. Wyniki leczenia i rokowania dla tych pacjentów nie są tak dobre, jak w przypadku pacjentów z wczesną diagnozą.

Słowa kluczowe: nowotwory prącia, rak, płaskonabłonkowy, wycięcie węzłów chłonnych

\section{Introduction}

Penile cancer is not a particularly common malignancy. Both in Europe and North America it occurs in fewer than 1 per 100000 males a year. In India it is 3, in Brazil 8,3 and in some African countries such as Uganda it reaches more than 10 [1]. Penile cancer is common in the regions with a high prevalence of human papillomavirus (HPV) [2]. Its incidence increases with patients' age, and reaches its peak in the sixth decade of life, though it can occur in any age.

There are risk factors that are well established. Those include phimosis, chronic penile inflammation, e.g. balanoposthitis, lichen sclerosus, Sporalene and UVA phototherapy for various dermatological conditions such as psoriasis, smoking, HPV type 16 and 18 infections. What is interesting is that neonatal circumcision decreases the risk of getting a penile cancer. Therefore, Israeli Jews have the lowest incidence of this illness in the world. However, adult circumcision does not reduce risk of PC [3].

More than 95\% cases of penile neoplasm are Squamous cell carcinoma (SCC) accounts, and the rest are caused mostly by basaloid carcinoma and melanoma. There are many mixed forms of SCC, including the warty-basaloid 
form (50-60\% of mixed penile SCC), usual-verrucous (hybrid), usual-warty, usual-basaloid or usual-papillary and other rarer combinations. Some lesions can be sporadically associated with SCC, e.g. a cutaneous horn of the penis, bowenoid papulosis of the penis, lichen sclerosus. Some lesions that are premalignant and up to onethird can transform in SCC- Intraepithelial neoplasia G3, Glant condylomata, erythroplasia of Queyrat, Bowen's disease and Paget's disease $[4,5,6,7]$.

Most cases of penile neoplasms are localised and treated at an early stage. An advanced form of the disease is visible only in about $5 \%$ cases of penile cancer.

The standard procedures that should be administered to the patient with advanced penile cancer T4 and positive lymph nodes at least $\mathrm{N} 1$ require a systemic approach. Neoadjuvant chemotherapy is performed before surgery. As an alternative, a palliative radiotherapy is an option. The operation covers total penectomy with perineal urethrostomy. The treatment of metastases in lymph nodes requires a systematic approach as well. Radical inguinal lymphadenectomy or even pelvic lymphadenectomy is an essential part of the procedure. It is usually postponed and performed as a 2 nd part of the surgical treatment due to possible complications, e.g. healing of the wound and lymph leakage. Adjuvant chemotherapy in patients with positive nodules pN2 and pN3 is recommended. Adjuvant chemotherapy for pN1 nodules is currently in the phase of clinical trials.

\section{Case description}

A 52-year-old male patient came to the urology outpatient unit on 26th September 2014 with a lesion that covered the skin of the whole penis, scrotum and lower part of the abdomen skin. According to the patient, it appeared 3 to 4 months earlier.

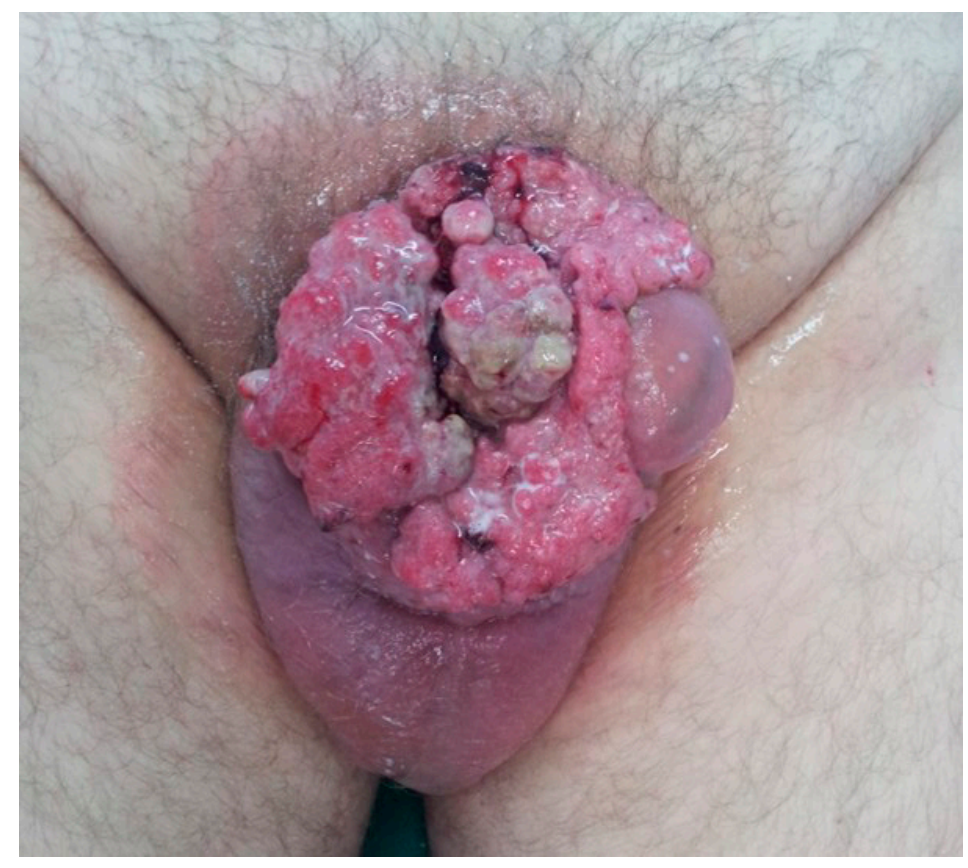

Figure 1. Penis with sizeable disintegrating tumour approximately $10 \mathrm{~cm}$ diameter

To evaluate the stage of the disease, the patient underwent a CT scan and screening panel for determining sexually transmitted infections. There was also performed a TRU-CUT biopsy of lymph nodes and penile specimen for a histopathologic test.

The abdomen and pelvis CT scan was done on 1st October 2014. Although MRI would be a better option to evaluate the stage of disease, CT was performed because of notably better availability. It showed that both the retroperitoneal, peritoneal lymph nodes and pelvic_lymph nodes were not enlarged. However, the inguinal lymph nodes were enlarged bilaterally - the right side dimensions up to $35 \times 22$ millimetres and the left side up to $34 \times 29 \mathrm{~mm}$. There were no more radiological signs of metastases both in the bone structures and parenchymal organs.

Also, the STD panel was negative.

The histopathologic result of TRU-CUT biopsy was available on 16th October 2014, and it showed that bilateral inguinal lymph nodes are occupied by metastases of squamous cell carcinoma. 
The treatment of the patient was divided into two parts. The first part aimed at performing radical penectomy, and the second one was reserved for radical pelvic lymphadenectomy that includes inguinal, iliac, obturatoral, sacral lymph nodes up to the bifurcation of the aorta. Although neoadjuvant chemotherapy was an option $[8,9,10]$ of the treatment, it was not administered to the patient because of its long-term availability and the surgical procedures could not be delayed.

A radical penectomy with bilateral orchiectomy was performed on 21st October 2014. Both tests were removed because of the risk of infiltration to achieve a clean oncological margin. The urethra was prepared carefully up to the healthy part, and then it was implanted into crotch as urostoma.

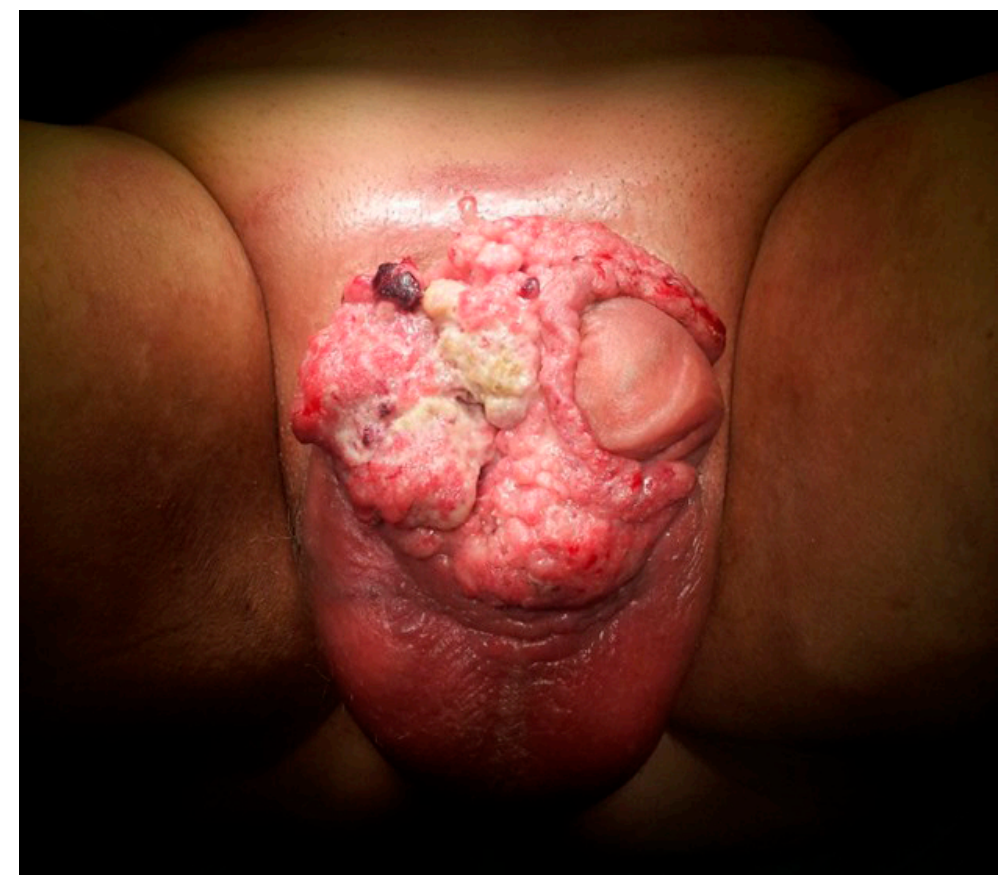

Figure 2. Penis with a sizeable disintegrating tumour before the first part of treatment

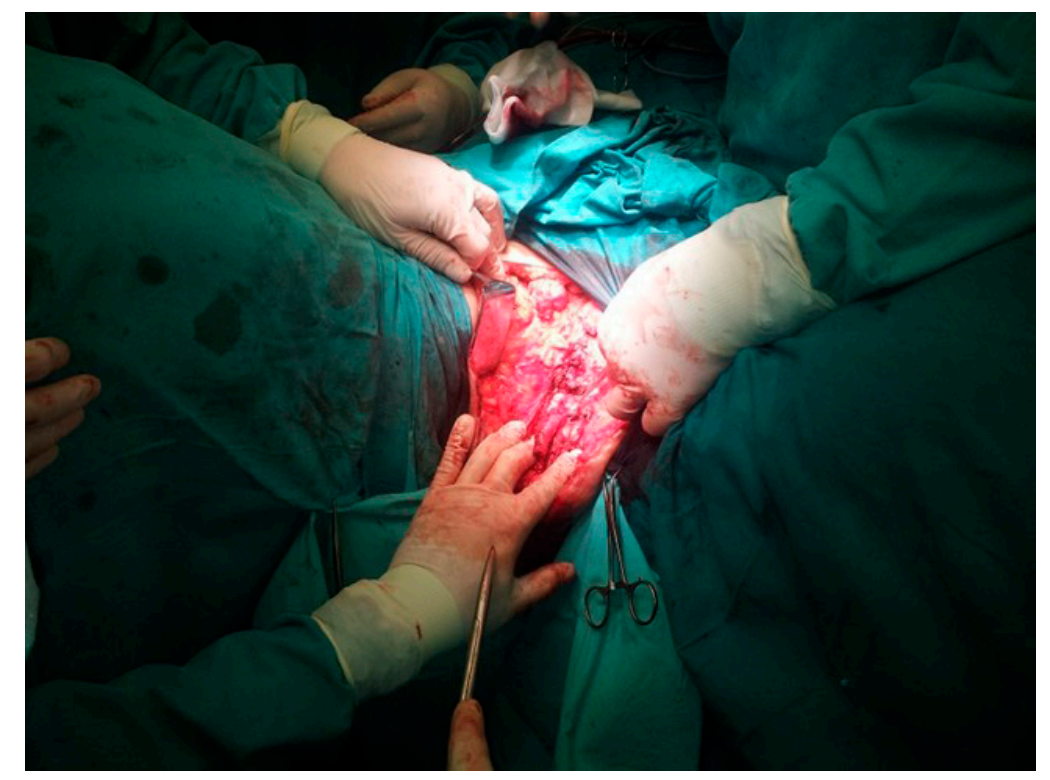

Figure 3. During the corpora cavernosa resection 


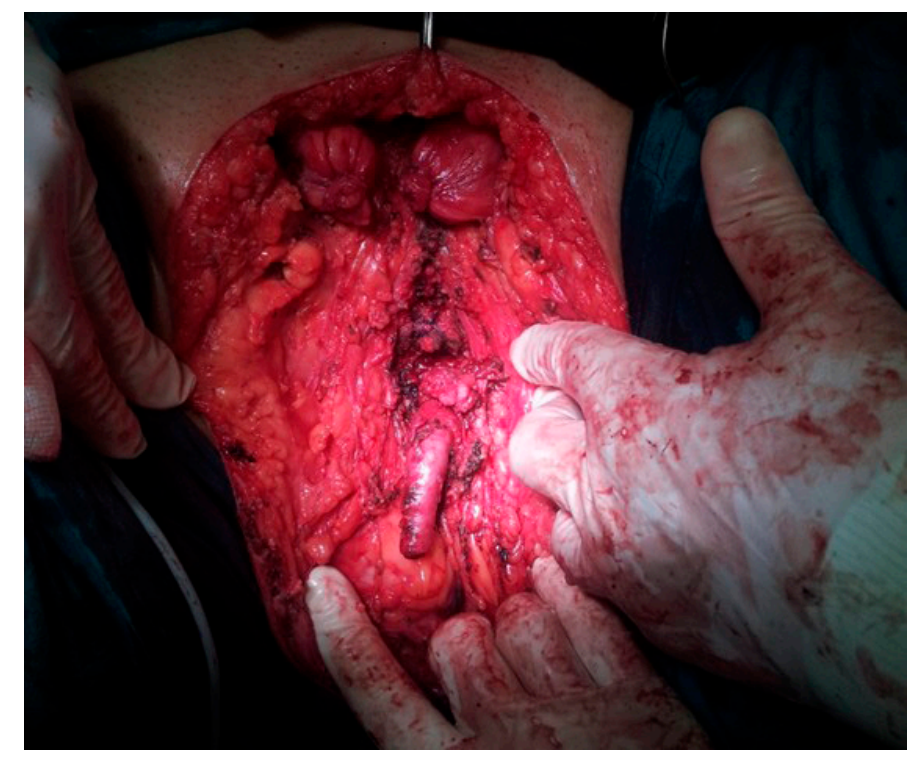

Figure 4. After the radical penile resection with prepared urethra

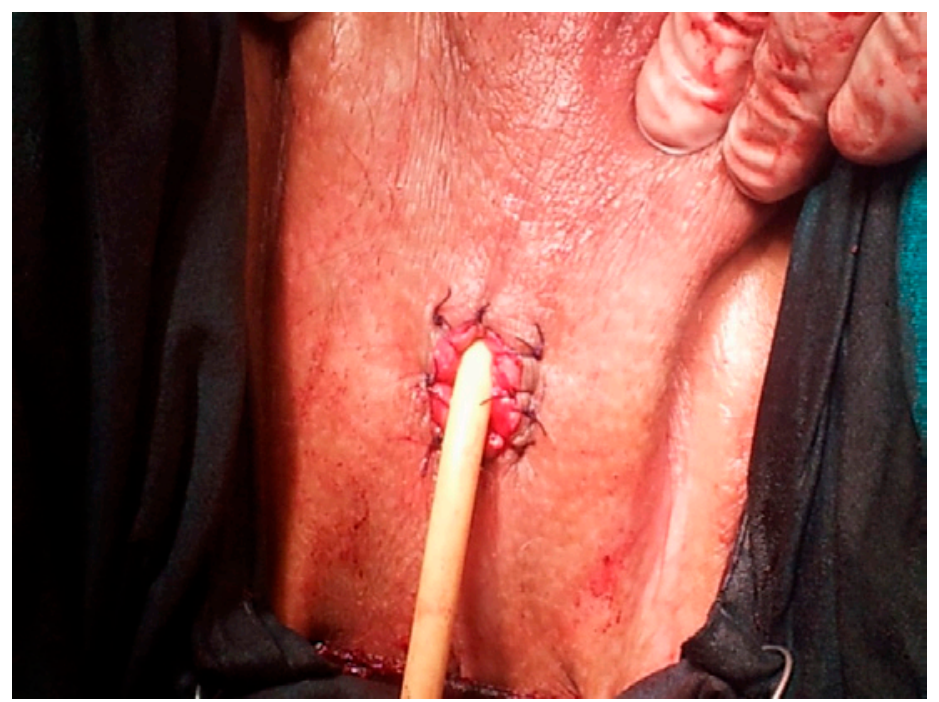

Figure 5. Urethra implanted into the crotch as urostoma

The histopathologic result of the 1st part of the treatment showed an 11-cm tumour of squamous cell carcinoma. The penis, its corpus cavernosum and scrotum with subcutaneous tissue were infiltrated by the tumour. Both tests were not covered by the carcinoma infiltration. The edges of incision were free of carcinoma cells. 


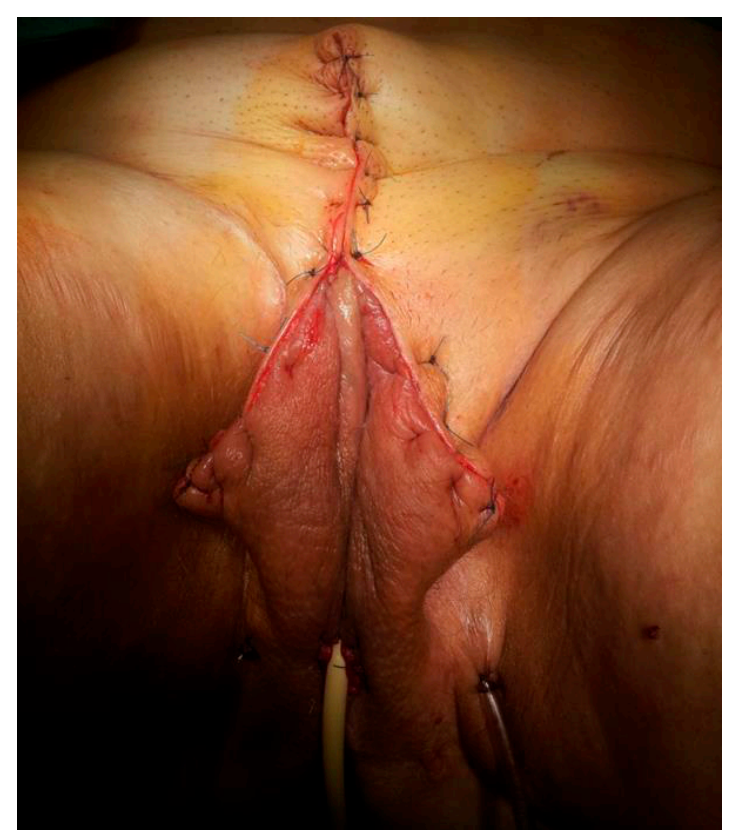

Figure 6. Overall view of the first part of surgical treatment.

As indicated above, after 5 weeks there was performed the 2 nd part of surgical treatment which covered radical pelvic lymphadenectomy that included inguinal, iliac, obturatoral, sacral lymph nodes up to the bifurcation of the aorta. After such extensive lymphadenectomy, there were expected complications such as skin necrosis above the inguinal canals and prolonged lymphatic leakage. To contraindicate these complications, we had to take some actions. Firstly, a part of the sartorius muscle was transplanted into the empty area of the inguinal canal after lymphadenectomy, and additionally, Spongostan material was placed to fulfil the space. Despite those measures, there was a prolonged lymphatic leakage that lasted for 45 days.

The histopathologic result of the 2nd part of the treatment showed that bilateral inguinal lymph nodes are occupied by metastases of squamous cell carcinoma. The right-sided iliac nodes were also occupied by metastases of squamous cell carcinoma. The remaining lymph nodes (left-sided iliac, obturatoral, sacral) were free of metastases.

After the whole surgical treatment, the patient was directed to a further oncologic therapy - adjuvant chemotherapy. However, he did not undergo the treatment because of personal reasons. Further, he did not appear for the surveillance, and no imaging scans were performed after the surgical procedure.

\section{Conclusions}

Although penile cancer is not a particularly common disease, its diagnosis is relatively easy. Male patients are aware of changes in the genitourinary area and usually come early to the urologic ambulatory. Hence most cases of penile cancer are diagnosed at early stages and can be treated radically. For all of those cases, an isolated resection of penile change or partial penectomy is usually a sufficient consideration. Histologically, penile cancer is very_homogeneous and more than $95 \%$ of all cases concern squamous cell carcinoma. This feature simplifies proceeding both in treatment and follows-up. The outcomes of the treatment and prognosis at early stages are excellent. It is different with an advanced penile cancer. As presented above, it is very scarce and requires a systematic approach. Surgical treatment is not enough, and adjuvant chemotherapy is often needed. Even after combined treatment, a routine follow-up is necessary because of a high risk of recurrence of neoplastic process and progression of distant metastases. Moreover, outcomes are not as good. The median overall survival for the men at that stage was 86.5 months and the 5 -year OS rate was $70.6 \%$, for localised disease $-77.9 \%$, regional metastases $-58.2 \%$, and for distant metastases $-16.7 \%$ [11]. 


\section{References:}

1. Parkin DM, Whelan SL, Ferlay J, Teppo L and Thomas DB Cancer Incidence in Five Continents, Vol. VIII, 2002, IARC Scientific Publications, No. 155, Lyon, IARC.

2. Backes DM, Kurman RJ, Pimenta JM, Smith JS Systematic review of human papillomavirus prevalence in invasive penile cancer. Cancer Causes Control, 2009; 20(4): 449-457

3. Dillner J, von Krogh G, Horenblas S, Meijer CJ Etiology of squamous cell carcinoma of the penis. Scand J Urol Nephrol Suppl, 2000;(205):189-93.

4. Velazquez EF, Barreto JE, Rodriguez I, Piris A, Cubilla AL, Limitations in the interpretation of biopsies in patients with penile squamous cell carcinoma. Int J Surg Pathol, 2004 Apr;12(2):139-46.

5. Velazquez EF, Cubilla AL Lichen sclerosus in 68 patients with squamous cell carcinoma of the penis: frequent atypias and correlation with special carcinoma variants suggests a precancerous role. Am J Surg Pathol, 2003 Nov;27(11):1448-53.

6. Teichman JM, Sea J, Thompson IM, Elston DM. Noninfectious penile lesions. Am Fam Physician, 2010 Jan 15;81(2):167-74.

7. Renaud-Vilmer C, Cavelier-Balloy B, Verola O, Morel P, Servant JM, Desgrandchamps F, et al. Analysis of alterations adjacent to invasive squamous cell carcinoma of the penis and their relationship with associated carcinoma. J Am Acad Dermatol, 2010 Feb;62(2):284-90. doi: 10.1016/j.jaad.2009.06.087.

8. Pizzocaro G., Piva L Adjuvant and neoadjuvant vincristine, bleomycin, and methotrexate for inguinal metastases from squamous cell carcinoma of the penis. Acta Oncol, 1988;27(6b):823-4.

9. Leijte JA, Kerst JM, Bais E, Antonini N, Horenblas S Neoadjuvant chemotherapy in advanced penile carcinoma. Eur Urol, 2007 Aug;52(2):488-94. Epub 2007 Feb 14.

10. Bermejo C, Busby JE, Spiess PE, Heller L, Pagliaro LC, Pettaway CA. Neoadjuvant chemotherapy followed by aggressive surgical consolidation for metastatic penile squamous cell carcinoma. J Urol, 2007 Apr;177(4):1335-8.

11. Patel MI, Yuminaga Y, Bang A, Lawrentschuk N, Skyring T and Smith DP (2016), Volume-outcome relationship in penile cancer treatment: a population based patterns of care and outcomes study from Australia. BJU Int, 2016 Oct;118 Suppl 3:35-42. doi: 10.1111/bju.13626. 